УДК 159.9.018:167.23

DOI https://doi.org/10.32838/2709-3093/2021.3/10

Садова М.A.

Таврійський національний університет імені В.І. Вернадського

\title{
ЕМПІРИЧНІ РЕЗУЛЬТАТИ ДОСЛІДЖЕНЬ ЗНАЧУЩИХ ВІДМІННОСТЕЙ У ЦІННІСНИХ ОРІЕНТАЦІЯХ ЩОДО ПРОФЕСІЙНОГО САМОВИЗНАЧЕННЯ ОБДАРОВАНОЇ МОЛОДІ
}

У статті здійснено аналіз емпіричних результатів досліджень значущих відмінностей у иіннісних орієнтаціях щзодо професійного самовизначення обдарованої молоді. Автором описаний вплив циіннісних орієнтацій на професійне самовизначення молоді за такими іноземними авторами, як: Н. Еліот, С. Черч, Т. Фрієдел, О. Леггетт, Р. Мохнюк, П. Кірпічник, В. Кімельблат, К. Кессел, Дю. Хочхеймер, С. Алмачі, 3. Охріменко, С. Райан, І. Дессі, К. Літтл, М. Кабаиька, О. Гітман, Д. Хорст. Відмінності в иіннісних орієнтаціях щодо професійного самовизначення обдарованої молоді вивчались такими авторами: Г. Мобергом, В. Гарн, Дж. Веселом, К. Моріс, К. Кемпбелл, С. Верном, Л. Ассор, К. Немієк, Р. Макос, М. Садовою, В. Каполом, Р. Свинаренком, К. Коселом.

Варто сказати, що за більшістю шкал иіннісних орієнтацій за статевими відмінностями краще проявили себе дівчатка щзодо вибору професії ("Самоспрямованість», «Стимуляиія», «Репутачія», «Конформність», «Покірність», «Доброзичливість», «Універсалізм»), ніж юнаки («Влада»).

За віковими відмінностями за більшістю шкал щзодо иіннісних орієнтацій за вибором професії краще проявили себе діти юнаџького віку, ніж підліткового. Це такі шкали, як «Самоспрямованість - думки», «Самоспрямованість - дї̈», «Репутація», «Традиції», «Конформність - міжособистісна», «Доброзичливість - піклування», «Універсалізм - природа».

За всіма шкалами, які пройшли рівні значущості в ціннісних орієнтаціях щодо вибору професії за рівнем академічної обдарованості, краще проявили себе академічно обдаровані діти, на відміну від необдарованої молоді ("Самоспрямованість - дї̈», «Стимулячія», «Влада домінування», «Конформність -міжособистісна»).

Отже, варто сказати, щңо за відповідними шкалами иіннісних орієнтацій щодо вибору професії за закладами освіти, у яких навчається обдарована молодь, краще проявили себе студенти закладів вищої освіти, ніж учні загальноосвітніх шкіл ("Конформність-правила», «Покірність»).

Ключові слова: иціннісні орієнтації, професійне самовизначення, рівні значущзості, диференціація, обдарованість.

Постановка проблеми. У процесі професійного самовизначення обдарована особистість орієнтуватиметься насамперед на ціннісні орієнтації та духовні якості, які впливатимуть на іiі формування. Статеві та гендерні відмінності в ціннісно-смисловій сфері відіграють велику роль у професійному самовизначенні щодо ризиконебезпечних професій. Відмінності щодо успішності в навчанні напряму залежать від академічної обдарованості учнів і абітурієнтів. Вікові відмінності дають можливість більш зріло та виважено підійти до обраної професії та становлення особистості, у ії прагненнях до самореалізації, самоздійснення, включають ціннісні орієнтації, ціннісні відношення і систему особистісних смислів.

Аналіз останніх досліджень і публікацій. Вплив ціннісних орієнтацій на професійне самовизначення молоді вивчали К. Кессел, Дж. Хочхеймер, С. Алмачі, 3. Охріменко, С. Райан, І. Дессі, К. Літтл, М. Кабацька, О. Гітман, Д. Хорст, Н. Еліот, С. Черч, Т. Фрієдел, О. Леггетт, Р. Мохнюк, П. Кірпічник, В. Кімельблат. Відмінності в ціннісних орієнтаціях щодо професійного самовизначення обдарованої молоді вивчались такими авторами: М. Садовою, В. Каполом, Р. Свинаренком, К. Коселом, Г. Мобергом, В. Гарн, Дж. Веселом, К. Моріс, К. Кемпбелл, С. Верном, Л. Ассор, К. Немієк, Р. Макос.

Не досить вивченими на емпіричному й експериментальному рівнях натепер $є$ відмінності в успішності навчання, статеві, вікові, гендерні відмінності в ціннісних орієнтаціях щодо професійного самовизначення обдарованої молоді. 
Постановка завдання. Мета статті - емпірично дослідити відмінності в ціннісних орієнтаціях щодо професійного самовизначення обдарованої молоді.

Виклад основного матеріалу дослідження. С. Алмачі особистісне і професійне самовизначення описує як невід'ємні складові частини ціннісно-смислового самовизначення [1, с. 39].

Дж. Хочхеймер розглядає успішність професійно-особистісного самовизначення обдарованої молоді не тільки і не стільки за критеріями персоналізації - ототожнення себе з якоюсь професійною роллю, досягнення професійного статусу, а передусім за критеріями персоніфікації - ідентифікації себе із професією на основі вироблення індивідуального способу існування в ній і водночас відкриття та збагачення свого «Я» через можливості професійної діяльності [2, с. 25].

Г. Моберг досліджував статеві відмінності за вибором професії, в основі яких були ризики $[4$, c. 50$]$.

П. Кірпічніков розглядає диференційні відмінності у професійному самовизначенні серед творчо й академічно обдарованих учнів $[6$, с. 70$]$.

М. Садова в кандидатській дисертації розглядала залежність творчої обдарованості від рівня креативності, успішності в навчанні - від інтелектуальної обдарованості та пізнавальних потреб і цінностей [8, с. 25].

В. Ален досліджує потреби у професійному самовизначенні (матеріальні, сімейні, пізнавальні, соціальні, потреби в безпеці, потреби моральні, естетичні), опираючись на концепцію П. Конгела $[10$, c. 15$]$

За допомогою математично-статистичного аналізу підрахунків у програмі SPSS (25 версіi) нами здійснювався поетапний аналіз результатів досліджень значущих відмінностей у ціннісних оріснтаціях щодо професійного самовизначення обдарованої молоді за критеріями Стьюдента ( $\mathrm{t}$ ) та Фішера (F):

- для початку підрахунків ми перевірили матриці емпіричних результатів дослідження (у програмі Excel) з вилученням досліджуваних, які не заповнили загальні дані та не пройшли Ціннісний опитувальник Ш. Шварца;

- із 392 досліджуваних якісні результати отримали лише 280 учасників;

- на наступному етапі ми сформували дошифратор, за яким здійснювались підрахунки, переносились до програми Excel;

- потім ми перенесли якісні результати дослідження до програми SPSS;

Статеві відмінності в ціннісних оріснтаціях

щодо професійного самовизначення обдарованої молоді

\begin{tabular}{|c|c|c|c|c|c|c|c|c|c|}
\hline Цінності & Стать & $\mathrm{N}$ & Середнє & $\begin{array}{l}\text { Станд. } \\
\text { відхи- } \\
\text { лення }\end{array}$ & $\begin{array}{c}\text { Станд. } \\
\text { середня } \\
\text { помилка }\end{array}$ & $\mathrm{F}$ & Знач. & $\mathrm{T}$ & $\begin{array}{c}\text { Знач. } \\
\text { (двосто- } \\
\text { роння) }\end{array}$ \\
\hline \multirow{2}{*}{ Цінність № 1} & Хлопці & 116 & 12,8621 & 2,75333 & 0,25564 & 1,168 & 281 & $-3,667$ & $0,000 * * *$ \\
\hline & Дівчата & 164 & 14,0244 & 2,50876 & 0,19590 & & & $\begin{array}{l}-3,609 \\
\end{array}$ & $0,000 * * *$ \\
\hline \multirow{2}{*}{ Цінність № 3} & Хлопці & 116 & 11,3276 & 2,24490 & 0,20843 & 1,136 & 0,287 & $-2,083$ & $0,038 * *$ \\
\hline & Дівчата & 164 & 11,9146 & 2,37679 & 0,18560 & & & $-2,103$ & $0,036^{* *}$ \\
\hline \multirow{2}{*}{ Цінність № 6} & Хлопці & 116 & 10,8190 & 3,54989 & 0,32960 & 1,337 & 249 & 1,738 & $0,083 * *$ \\
\hline & Дівчата & 164 & 10,1037 & 3,27777 & 0,25 & & & 1,714 & $0,088 * *$ \\
\hline \multirow{2}{*}{ Цінність № 8} & Хлоп & 116 & 12,8534 & 2,47862 & 0,23013 & 0,392 & 0,532 & $-2,712$ & $0,007 * * *$ \\
\hline & Дівчата & 164 & 13,6463 & 2,35954 & 0,18 & & & $-2,690$ & $0,008 * * *$ \\
\hline \multirow{2}{*}{$\begin{array}{c}\text { Цінність № } \\
13\end{array}$} & Хлоп & 116 & 12,1983 & 2,61175 & 0,24249 & 4,206 & $0,041^{* *}$ & $-1,815$ & $0,071^{*}$ \\
\hline & Дівч: & 164 & 12,8293 & 3,03277 & 0,23682 & & & $-1,862$ & $0,064 *$ \\
\hline \multirow{2}{*}{$\begin{array}{c}\text { Цінність № } \\
14\end{array}$} & Хлог & 116 & 11,1466 & 2,51346 & 0,23337 & 2,931 & $0,088^{* *}$ & 1,167 & 0,244 \\
\hline & Дівч: & 164 & 10,7622 & 2,84759 & 0,22236 & & & 1,192 & 0,234 \\
\hline \multirow{2}{*}{$\begin{array}{c}\text { Цінність № } \\
15 \\
\end{array}$} & Хлог & 11 & 776 & 2,43221 & 0,22583 & 0,231 & 0,631 & $-3,360$ & $0,001 * * *$ \\
\hline & Дівчата & 164 & 14,0305 & 2,26855 & 0,17714 & & & $-3,320$ & $0,001 * * *$ \\
\hline \multirow{2}{*}{$\begin{array}{c}\text { Цінність № } \\
16 \\
\end{array}$} & Хлопц & 116 & 14,1207 & 2,35226 & 0,21840 & 0,107 & 0,744 & $-2,770$ & $0,006^{* * *}$ \\
\hline & Дівчата & 164 & 14,8963 & 2,27717 & 0,17782 & & & $-2,754$ & $0,006 * * *$ \\
\hline \multirow{2}{*}{$\begin{array}{c}\text { Цінність № } \\
17 \\
\end{array}$} & Хлопь & 116 & 12,4828 & 2,14063 & 0,19875 & 2,850 & $0,093 * *$ & $-5,132$ & $0,000 * * *$ \\
\hline & Дівчат & 164 & 13,9512 & 2,50105 & 0,19530 & & & $-5,270$ & $0,000 * * *$ \\
\hline \multirow{2}{*}{$\begin{array}{c}\text { Цінність № } \\
18 \\
\end{array}$} & Хлоп & 110 & 12,0259 & 3,35821 & 0,31180 & 0,296 & 0,587 & $-2,968$ & $0,003 * * *$ \\
\hline & Дівчата & 164 & 13,1829 & 3,10799 & 0,24269 & & & $-2,928$ & $0,004 * * *$ \\
\hline
\end{tabular}


- на наступному етапі ми здійснили підрахунки у програмі SPSS значущих відмінностей у ціннісних орієнтаціях щодо професійного самовизначення обдарованої молоді: за віковими, статевими відмінностями, успішності в навчанні, академічної обдарованості, а також у відмінностях щодо навчання в різних закладах освіти;

- на заключному етапі здійснили аналіз цифрових результатів дослідження проблеми за t-критерієм Стьюдента та F-критерієм Фішера, що подається нижче до кожної з наведених таблиць.

Стосовно аналізу статевих відмінностей у ціннісних орієнтаціях щодо професійного самовизначення обдарованої молоді за таблицею 1, варто зазначити, що в дослідженні взяли участь 164 дівчини і 116 хлопців.

За двосторонньою значущістю розбіжностей між показниками дівчат та хлопців на одновідсотковому рівні $(\mathrm{p} \leq 0,01)$ за $\mathrm{t}$-критерієм Стьюдента виявлені цінності № № 1, 8, 15, 16, 17, 18.

На п'ятивідсотковому рівні значущості $(\mathrm{p} \leq 0,05)$ за t-критерієм Стьюдента виявлені лише шкали ціннісних орієнтацій таких цінностей № № 6,3 i 13 .

На десятивідсотковому рівні значущості $(\mathrm{p} \leq 0,1)$ за $\mathrm{t}$-критерієм Стьюдента не виявлено жодної шкали ціннісних оріснтацій.

За F-критерієм Фішера на одновідсотковому рівні $(\mathrm{p} \leq 0,01)$ не спрацювала жодна шкала щодо ціннісних орієнтацій; на п'ятивідсотковому рівні значущості $(\mathrm{p} \leq 0,05)$ спрацювали лише шкали № № 13 і 17, на десятивідсотковому рівні значущості $(\mathrm{p} \leq 0,1)$ не спрацювали шкали.

Здійснимо аналіз середніх значень за шкалами Опитувальника ціннісних орієнтацій Ш. Шварца, які проявили себе за рівнями значущості, переліченими вище.

Цінність № 1 «Самоспрямованість - думки (свобода культивувати власні ідеї та переконання)» краще проявила себе за середніми значеннями в дівчаток (14), на відміну від хлопчиків $(12,8)$, що свідчить про більш мислиннєво спрямовані та переконливі у виборі професії саме дівчат, на відміну від хлопців.

Цінність № 3 «Стимуляція (азарт, новизна, зміни)» мало проявила себе за статевими відмінностями: у хлопчиків - 11,3, у дівчаток - 11,9. Більше прагнуть до новизни та змін щодо вибору професії дівчатка, як показує аналіз результатів шкали.

Цінність № 6 «Влада - ресурси (влада через контроль матеріальних та соціальних ресурсів)» мало проявилася за статевими відмінностями: у хлопчиків - 10,8, у дівчаток - 10,1. Як бачимо, хлопчики більш прагнуть до професій, які пов'язані із владою та контролем, на відміну від дівчат. Отже, у юнаків закладено панівну функцію і кар'єрні домагання із професійним самовизначенням.

Цінність № 8 «Репутація (безпека та влада через підтримку іміджу)» добре проявилася за статевими відмінностями: у хлопчиків - 12,8, у дівчаток - 13,6, що свідчить про те, що вибір професії, який грунтуватиметься на іміджі, репутації, для дівчат значно важливіший, ніж у хлопців.

Цінність № 13 «Конформність - міжособистісна (догоджання іншим)» мало проявилася за статевими відмінностями: у хлопчиків - 12,2, у дівчаток - 12,8. Проте більше догоджати іншим у виборі професії будуть дівчатка, як показує аналіз результатів шкали.

Цінність № 14 «Покірність (власна незначність)» непогано проявилася за статевими відмінностями: у хлопчиків - 11,1 , у дівчаток 10,8. Більш покірними у виборі професії будуть дівчатка, як показує аналіз результатів шкали.

Цінність № 15 «Доброзичливість - надійність (надійний член групи)» непогано проявилася за статевими відмінностями: у хлопчиків - 13, у дівчаток - 14. Більш надійними в команді у виборі професії будуть дівчатка, як показує аналіз результатів шкали.

Цінність № 16 «Доброзичливість - піклування (відданість добробуту членів групи)» добре проявилася за статевими відмінностями: у хлопчиків 14,1, у дівчаток - 14,9. Проте більше піклуватись про групу як колектив у виборі професії будуть дівчатка, як показує аналіз результатів шкали.

Цінність № 17 «Універсалізм - турбота (ствердження справедливості, рівності й захисту всіх людей)» дуже добре проявилася за статевими відмінностями: у хлопчиків - 12,5, у дівчаток -14 . Більше піклуватись за рівні права в колективі щодо вибору професії будуть дівчатка, як показує аналіз результатів шкали.

Цінність № 18 «Універсалізм - природа (збереження природного середовища)» добре проявилася за статевими відмінностями: у хлопчиків -12 , у дівчаток - 13,2. Проте більше піклуватись про навколишнє середовище (об'єктивні чинники у виборі професіі) будуть дівчатка, як показує аналіз результатів шкали.

Отже, варто сказати, що за більшістю шкал ціннісних орієнтацій за статевими відмінностями краще проявили себе дівчатка щодо вибору професії, ніж хлопчики. 
Щодо проведеного аналізу вікових відмінностей у ціннісних орієнтаціях щодо професійного самовизначення обдарованої молоді за таблицею 2 варто зазначити, що в дослідженні взяли участь 142 учасники юнацького та 138 учасників підліткового віку.

За двосторонньою значущістю розбіжностей між показниками дівчат та хлопців на одновідсотковому рівні $(\mathrm{p} \leq 0,01)$ за $\mathrm{t}$-критерієм Стьюдента не виявлено жодної цінності за запропонованими шкалами опитувальника Ш. Шварца.

На п'ятивідсотковому рівні значущості $(\mathrm{p} \leq 0,05)$ за $\mathrm{t}$-критерієм Стьюдента виявлені лише шкали ціннісних орієнтацій № № 1, 7, 8, 11, 16, 17.

На десятивідсотковому рівні значущості $(\mathrm{p} \leq 0,1)$ за t-критерієм Стьюдента виявлені шкали ціннісних орієнтацій № № 6, 13, 19.

За F-критерієм Фішера на одновідсотковому рівні $(\mathrm{p} \leq 0,01)$ спрацювала лише одна шкала щодо ціннісних орієнтацій № 2; на п’ятивідсотковому рівні значущості $(\mathrm{p} \leq 0,05)$ спрацювали шкали № № $8,14,16$, на десятивідсотковому рівні значущості $(\mathrm{p} \leq 0,1)$ не спрацювала жодна шкала.

Здійснимо аналіз середніх значень за шкалами Опитувальника ціннісних орієнтацій Ш. Шварца, які проявили себе за рівнями значущості, переліченими вище.

Цінність № 1 «Самоспрямованість - думки (свобода культивувати власні ідеї та переконання)» краще проявилася за середніми значеннями в юнаків $(13,9)$, на відміну від підлітків $(13,2)$, що свідчить про те, що більш мислиннєво спрямовані та переконливі у виборі професії діти старшого віку, ніж молодшого.

Цінність № 2 «Самоспрямованість - дії (свобода дії відповідно до власних переконань)» мало проявилася за віковим діапазоном: у юнаків $-14,3$, у підлітків - 14,2. Більш рішучі в діях щодо вибору професії діти юнацького віку, як показує аналіз результатів шкали.

Цінність № 6 «Влада - ресурси (влада через контроль матеріальних та соціальних ресурсів)» мало проявилася за віковим діапазоном: у юнаків 10, у підлітків - 10,7. Як бачимо, діти юнацького віку більш прагнуть до професій, які пов'язані із владою та контролем, на відміну від підлітків.

Цінність № 7 «Влада - домінування (влада через контроль над іншими)» добре проявилася за віковими відмінностями: у юнаків - 10,5, у підлітків $-11,5$, що свідчить про частіший вибір підлітками професії, який грунтуватиметься на

Таблиця 2

Вікові відмінності в ціннісних оріснтаціях щодо професійного самовизначення обдарованої молоді

\begin{tabular}{|c|c|c|c|c|c|c|c|c|}
\hline Цінності & Вік & $\mathrm{N}$ & Середнє & \begin{tabular}{|c} 
Станд. від- \\
хилення
\end{tabular} & $\mathrm{F}$ & Знач. & $\mathrm{T}$ & $\begin{array}{l}\text { знач. (дво- } \\
\text { стороння) }\end{array}$ \\
\hline \multirow{2}{*}{ Цінність № 1} & Юнацький & 142 & 13,9014 & 2,59926 & 1,260 & 0,263 & 2,297 & $0,022 * *$ \\
\hline & Підлітковий & 138 & 13,1739 & 2,70148 & & & 2,295 & $0,022 * *$ \\
\hline \multirow{2}{*}{ Цінність № 2} & Юнацький & 142 & 14,2958 & 1,95984 & 9,262 & $0,003 * * *$ & 0,452 & 0,652 \\
\hline & Підлітковий & 138 & 14,1739 & 2,52553 & & & 0,450 & 0,653 \\
\hline \multirow{2}{*}{ Цінність № 7} & Юнацький & 142 & 10,5211 & 2,96963 & 1,185 & 0,277 & $-2,567$ & $0,011^{* *}$ \\
\hline & Підлітковий & 138 & 11,4783 & 3,26722 & & & $-2,563$ & $0,011^{* *}$ \\
\hline \multirow{2}{*}{ Цінність № 8} & Юнацький & 142 & 13,6831 & 2,19403 & 5,274 & $0,022 * *$ & 2,570 & $0,011^{* *}$ \\
\hline & Підлітковий & 138 & 12,9420 & 2,61876 & & & 2,563 & $0,011^{* *}$ \\
\hline \multirow{2}{*}{ Цінність № 11} & Юнацький & 142 & 10,8521 & 3,57681 & 0,023 & 0,880 & 2,398 & $0,017 * *$ \\
\hline & Підлітковий & 138 & 9,8043 & 3,73552 & & & 2,396 & $0,017 * *$ \\
\hline \multirow{2}{*}{ Цінність № 13} & Юнацький & 142 & 12,8592 & 2,88943 & 0,077 & 0,782 & 1,724 & $0,086^{*}$ \\
\hline & Підлітковий & 138 & 12,2681 & 2,84525 & & & 1,725 & $0,086^{*}$ \\
\hline \multirow{2}{*}{ Цінність № 14} & Юнацький & 142 & 10,8662 & 2,89100 & 5,440 & $0,020 * *$ & $-0,345$ & 0,731 \\
\hline & Підлітковий & 138 & 10,9783 & 2,53290 & & & $-0,345$ & 0,730 \\
\hline \multirow{2}{*}{ Цінність № 16} & Юнацький & 142 & 14,9155 & 2,09523 & 6,012 & $0,015^{* *}$ & 2,497 & $0,013 * *$ \\
\hline & Підлітковий & 138 & 14,2246 & 2,52005 & & & 2,491 & $0,013 * *$ \\
\hline \multirow{2}{*}{ Цінність № 17} & Юнацький & 142 & 13,6761 & 2,44818 & 0,106 & 0,745 & 2,314 & $0,021 * *$ \\
\hline & Підлітковий & 138 & 13,0000 & 2,44053 & & & 2,314 & $0,021 * *$ \\
\hline \multirow{2}{*}{ Цінність № 19} & Юнацький & 142 & 12,1620 & 2,42808 & 0,408 & 0,524 & 1,927 & $0,055^{*}$ \\
\hline & Підлітковий & 138 & 11,5725 & 2,68787 & & & 1,924 & $0,055^{*}$ \\
\hline
\end{tabular}


можливості контролю над іншими. Це можна аргументувати з позиції надмірного егоцентризму та перфекціонізму в підлітковому віці.

Цінність № 8 «Репутація (безпека та влада через підтримку іміджу)» добре проявилася за віковими відмінностями: у дітей юнацького віку 13,7, підліткового - 13, що свідчить про те, що вибір професії, який грунтуватиметься на іміджі, репутації, у юнацькому віці значно важливіший, на відміну від підлітків.

Цінність № 10 «Безпека - суспільна (безпека та стабільність загалом у суспільстві)» непогано проявилася за віковими відмінностями: у юнаків - 13,5, у підлітків - 13. Більш безпечні професії вибиратимуть юнаки, на відміну від підлітків.

Цінність № 11 «Традиції (збереження культурних, сімейних чи релігійних традицій)» непогано проявилася за віковими відмінностями: у дітей юнацького віку - 10,9, у підлітків - 9,8. Більше прагнуть зберегти сімейні традиції у виборі професії діти юнацького віку, як показує аналіз результатів за шкалою.

Цінність № 13 «Конформність - міжособистісна (догоджання іншим)» мало проявилася за віковими відмінностями: у юнаків - 12,9 , у підлітків - 12,3. Більше догоджати іншим у виборі професії будуть діти юнацького віку, як показує аналіз результатів за шкалою.

Цінність № 14 «Покірність (власна незначність)» слабо проявилася за статевими відмінностями: у дітей юнацького віку - 10,9, у підлітків - 11. Більш покірними у виборі професії будуть підлітки, як показує аналіз результатів за шкалою.

Цінність № 16 «Доброзичливість - піклування (відданість добробуту членів групи)» добре проявилася за віковими відмінностями: у юнаків - 14,9, у підлітків - 14,2. Більше піклуватись про групу як колектив у виборі професії будуть діти юнацького віку, як показує аналіз результатів за шкалою.
Цінність № 17 «Універсалізм - турбота (ствердження справедливості, рівності й захисту всіх людей)» добре проявилася за віковими відмінностями: у юнаків - 13,7, у підлітків - 13. Більше піклуватись про рівні права в колективі щодо вибору професії будуть юнаки, як показує аналіз результатів за шкалою.

Цінність № 19 «Універсалізм - толерантність (прийняття та розуміння інших)» добре проявилася за віковими відмінностями: у юнаків - 13, у підлітків - 12. Краще розуміти і більше прислухатись до думки інших у виборі професії будуть юнаки, на відміну від підлітків.

Отже, варто сказати, що за більшістю шкал ціннісних орієнтацій щодо вибору професії за віковими відмінностями краще проявили себе діти юнацького віку, ніж підліткового.

Наведемо результати аналізу відмінностей у ціннісних орієнтаціях щодо професійного самовизначення за закладами освіти, у яких навчається обдарована молодь, за таблицею 3. У дослідженні взяли участь 224 студенти закладів вищої освіти (далі 3ВО) та 56 учнів загальноосвітніх шкіл (далі - ЗОШ).

За двосторонньою значущістю розбіжностей на одновідсотковому $(\mathrm{p} \leq 0,01)$ та п'ятивідсотвому рівнях $(\mathrm{p} \leq 0,05)$ за t-критерієм Стьюдента між показниками студентів ЗВО та учнів ЗОШ не виявлено жодної цінності за запропонованими шкалами опитувальника Ш. Шварца.

На десятивідсотковому рівні значущості $(\mathrm{p} \leq 0,1)$ за t-критерієм Стьюдента виявлена лише шкала ціннісних орієнтацій № 2.

За F-критерієм Фішера виявлені шкали лише на п'ятивідсотковому рівні значущості $(\mathrm{p} \leq 0,05)$ № № 2 i 5.

Здійснимо аналіз середніх значень за шкалами Опитувальника ціннісних орієнтацій Ш. Шварца, які проявили себе за рівнями значущості, переліченими вище.

Таблиця 3

\section{Відмінності в ціннісних оріснтаціях щодо професійного самовизначення} за закладами освіти, у яких навчасться обдарована молодь

\begin{tabular}{|c|c|c|c|c|c|c|c|c|}
\hline \multirow{2}{*}{ Цінності } & Заклад освіти & $\mathrm{N}$ & Середнє & $\begin{array}{c}\text { Станд. } \\
\text { відхи- } \\
\text { лення }\end{array}$ & $\mathrm{F}$ & Знач. & т & $\begin{array}{c}\text { Знач. } \\
\text { (двосто- } \\
\text { роння) }\end{array}$ \\
\hline Цінніст № 2 & $\begin{array}{c}\text { Вищий навчаль- } \\
\text { ний заклад }\end{array}$ & 224 & 14,3661 & 2,14077 & 4,036 & $0,046^{* *}$ & 1,946 & $0,053^{*}$ \\
\cline { 2 - 9 } & $\begin{array}{c}\text { Загальноосвітня } \\
\text { школа }\end{array}$ & 56 & 13,7143 & 2,61266 & & & 1,728 & $0,088^{*}$ \\
\hline \multirow{2}{*}{$\begin{array}{c}\text { Цінність } \\
\text { № 5 }\end{array}$} & $\begin{array}{c}\text { Вищий навчаль- } \\
\text { ний заклад }\end{array}$ & 224 & 12,9777 & 2,41528 & 3,987 & $0,047 * *$ & 1,384 & 0,167 \\
\cline { 2 - 9 } & $\begin{array}{c}\text { Загьносвітня } \\
\text { школа }\end{array}$ & 56 & 12,4464 & 3,11547 & & & 1,190 & 0,238 \\
\hline
\end{tabular}


Цінність № 2 «Самоспрямованість - дії (свобода дії відповідно до власних переконань)» мало проявилася за відповідними закладами освіти: у студентів ЗВО - 14,3, в учнів ЗОШ - 13,7. Більш рішучі в діях студенти ЗВО щодо вибору професії, як показує аналіз результатів за шкалою.

Цінність № 5 «Досягнення (успіх відповідно до соціальних стандартів)» мало проявилася за закладами освіти: у студентів $3 \mathrm{BO}-13$, в учнів ЗОШ - 12,4. Як бачимо, студенти ЗВО більше прагнуть до професій, які пов'язані з успіхом, відповідно до соціальних стандартів, на відміну від учнів ЗОШ.

Отже, за відповідними шкалами ціннісних орієнтацій щодо вибору професії за закладами освіти, у яких навчається обдарована молодь, краще проявили себе студенти ЗВО, ніж учні ЗОШ.

У процесі проведення аналізу відмінностей у ціннісних орієнтаціях щодо професійного самовизначення академічно обдарованої молоді за таблицею 4 варто зазначити, що в дослідженні взяли участь 86 академічно обдарованих учасників та 194 академічно необдарованих учасників освітнього процесу.

За двосторонньою значущістю розбіжностей між показниками академічної обдарованості на одновідсотковому $(\mathrm{p} \leq 0,01)$ та п'ятивідсотковому рівнях значущості $(\mathrm{p} \leq 0,05)$ за $\mathrm{t}$-критерієм Стьюдента не виявлено жодної цінності за запропонованими шкалами опитувальника Ш. Шварца.
На десятивідсотковому рівні значущості $(\mathrm{p} \leq 0,1)$ за t-критерієм Стьюдента виявлені шкали ціннісних орієнтацій № № 2, 3, 7 .

За F-критерієм Фішера на одновідсотковому piвні $(\mathrm{p} \leq 0,01)$ спрацювала лише одна шкала щодо ціннісних орієнтацій № 14; на п’ятивідсотковому та десятивідсотковому рівнях значущості $(\mathrm{p} \leq 0,1)$ не спрацювала жодна шкала.

Здійснимо аналіз середніх значень за шкалами Опитувальника ціннісних орієнтацій Ш. Шварца, які проявили себе за рівнями значущості, переліченими вище.

Цінність № 2 «Самоспрямованість - дії (свобода дії відповідно до власних переконань)» непогано проявилася за академічною обдарованістю учасників освітнього процесу: в академічно обдарованих $-14,6$, в академічно необдарованих -14 . Більш рішучі в діях академічно обдаровані учасники освітнього процесу щодо вибору професії, як показує аналіз результатів за шкалою.

Цінність № 3 «Стимуляція (азарт, новизна, зміни)» непогано проявилася за рівнем академічної обдарованості: в академічно обдарованих - 12, в академічно необдарованих - 11,5. Більше прагне до новизни та змін щодо вибору професії академічно обдарована молодь, як показує аналіз результатів за шкалою.

Цінність № 7 «Влада - домінування (влада через контроль над іншими)» непогано проявилася за рівнем академічної обдарованості: в академічно обдарованих - 11,5 , в академічно

Таблиця 4

\section{Відмінності в ціннісних оріснтаціях щодо професійного самовизначення} академічно обдарованої молоді

\begin{tabular}{|c|c|c|c|c|c|c|c|c|}
\hline Цінності & $\begin{array}{c}\text { Рівень академіч- } \\
\text { ної обдарова- } \\
\text { ності }\end{array}$ & $\mathrm{N}$ & Середнє & $\begin{array}{c}\text { Станд. від- } \\
\text { хилення }\end{array}$ & $\mathrm{F}$ & Знач. & $\mathrm{T}$ & $\begin{array}{l}\text { Знач. (дво- } \\
\text { стороння) }\end{array}$ \\
\hline \multirow[t]{2}{*}{ Цінність № 2} & $\begin{array}{l}\text { Академічно } \\
\text { обдаровані }\end{array}$ & 86 & 14,6047 & 2,16539 & 0,114 & 0,736 & 1,832 & $0,068^{*}$ \\
\hline & $\begin{array}{l}\text { Академічно нео- } \\
\text { бдаровані }\end{array}$ & 194 & 14,0722 & 2,27738 & & & 1,868 & $0,063^{*}$ \\
\hline \multirow[t]{2}{*}{ Цінність № 3} & $\begin{array}{c}\text { Академічно } \\
\text { обдаровані }\end{array}$ & 86 & 12,0581 & 2,31798 & 0,255 & 0,614 & 1,852 & $0,065^{*}$ \\
\hline & $\begin{array}{c}\text { Академічно нео- } \\
\text { бдаровані }\end{array}$ & 194 & 11,5000 & 2,33080 & & & 1,856 & $0,065^{*}$ \\
\hline \multirow[t]{2}{*}{ Цінність № 7} & $\begin{array}{l}\text { Академічно } \\
\text { обдаровані }\end{array}$ & 86 & 11,5000 & 2,99706 & 0,427 & 0,514 & 1,800 & $0,073^{*}$ \\
\hline & $\begin{array}{c}\text { Академічно нео- } \\
\text { бдаровані }\end{array}$ & 194 & 10,7680 & 3,19858 & & & 1,846 & $0,067 *$ \\
\hline \multirow[t]{2}{*}{ Цінність № 14} & $\begin{array}{l}\text { Академічно } \\
\text { обдаровані }\end{array}$ & 86 & 11,2326 & 2,27867 & 7,292 & $0,007 * * *$ & 1,278 & 0,202 \\
\hline & $\begin{array}{l}\text { Академічно нео- } \\
\text { бдаровані }\end{array}$ & 194 & 10,7835 & 2,88367 & & & 1,398 & 0,164 \\
\hline
\end{tabular}


необдарованих - 10,8, що свідчить про вибір професії, який грунтуватиметься на контролі над іншими, в академічно обдарованої молоді показник значно кращий. Це можна аргументувати 3 позиції надмірного перфекціонізму в академічно обдарованих учасників освітнього процесу.

Цінність № 14 «Покірність (власна незначність)» слабо проявилася за статевими відмінностями: в академічно обдарованих - 11,2, в академічно необдарованих - 10,8. Тому більш покірна у виборі професії буде академічно обдарована молодь, як показує аналіз результатів за шкалою.

Отже, за більшістю шкал ціннісних орієнтацій щодо вибору професії за рівнем академічної обдарованості краще проявили себе академічно обдаровані діти, на відміну від необдарованої молоді.

Висновки. Варто сказати, що за більшістю шкал ціннісних орієнтацій за статевими відмінностями краще проявили себе дівчатка щодо вибору професії («Самоспрямованість», «Стимуляція», «Репутація», «Конформність», «Покірність», «Доброзичливість», «Універсалізм»), ніж юнаки («Влада»).
За віковими відмінностями за більшістю шкал щодо ціннісних орієнтацій за вибором професії краще проявили себе діти юнацького віку, ніж підліткового. Це такі шкали, як «Самоспрямованість - думки», «Самоспрямованість - дії», «Репутація», «Традиції», «Конформність - міжособистісна», «Доброзичливість - піклування», «Універсалізм - природа».

За всіма шкалами, які пройшли рівні значущості в ціннісних орієнтаціях щодо вибору професії за рівнем академічної обдарованості, краще проявили себе діти академічно обдаровані, на відміну від необдарованої молоді («Самоспрямованість - дії», «Стимуляція», «Влада - домінування», «Конформність - міжособистісна»).

Отже, за відповідними шкалами ціннісних орієнтацій щодо вибору професії за закладами освіти, у яких навчається обдарована молодь, краще проявили себе студенти 3ВО, ніж учні ЗОШ («Конформність - правила», «Покірність»).

Перспективи подальших розробок полягають у тому, щоб експериментально досліджувати творчо обдаровану молодь ЗВО, розробляти діагностичний інструментарій для виявлення таких студентів.

\section{Список літератури:}

1. Almashi S. Value orientation as a basis for the formation of professional competence. Science and Education a New Dimension. Pedagogy and Psychology. 2014. II (13). Iss. 26. P. 38-50.

2. Hochheimer J. Communication, Spirituality and the Sharingof Meaning. Spirituality: Theory, Praxis and Pedagogy, Published / Martin Fowler, John D. Martin III and John Hochheimer (eds). Oxford, UK : InterDisciplinary Press, 2017. P. 21-28.

3. Koessel K. The Relationship between Spirituality and Personality : Ph. D. dis. Unites States, Kalamazoo, Michigan, 2011.202 p.

4. Moberg D. Assessing and Measuring Spirituality: Confronting Dilemmas of Universal and Particular Evaluative Criteria. Journal of Adult Development. 2012. № 9 (1). P. 47-60.

5. Recognition and Teaching Gifted and Talented Children - Good Practice for Europe. 2019. P. 4-12. URL: https://www.talentedchildrenproject.eu/images/zpravy/Recognition\%20and\%20Teaching\%20Gifted.pdf.

6. Ibrasheva L. Interrelation of value orientations and professional self-determination of senior students in the system Lyceum-KNRTU-enterprise : SScPhD. Associate Professor, principal of boarding lyceum for gifted children named after Academician P. A. Kirpichnikov, with advanced study in chemistry "KNRTU". P. 66-80. URL: https://nougazprom.mskobr.ru/files/Ibrascheva_eng.pdf.

7. Features of formation of the motivational-value complex of the musically gifted youth. July 6, 2019. P. 70-80. URL: https://evnuir.vnu.edu.ua/handle/123456789/15899.

8. Developing Creativity in Gifted Children : The Central Importance of Motivation and Classroom Climate 2012. Research Article. P. 18-32. URL: https://files.eric.ed.gov/fulltext/ED505478.pdf.

9. Parental Influences on the Academic Motivation of Gifted Students: A Self Determination Theory Perspective Alex C. Garn1, Michael S. Matthews, and Jennifer L. Jolly. October 2015. P. 20-25. URL: https://selfdeterminationtheory.org/SDT/documents/2010_GarnMatthewsetal_GCQ.pdf.

10. Gottfried Allen W. Development of Gifted Motivation : Longitudinal Research and Applications. URL: https://link.springer.com/chapter/10.1007/978-1-4020-6162-2_30.

11. Marzooghi R., Sheikholeslami R., Shamshiri B. Comparing Achievement Goal Orientations of Iranian Gifted and Nongifted Schoolchildren. URL: https://scialert.net/fulltext/?doi=jas.2009.1990.1993.

12. Research of spiritual and moral values of students of classical and pedagogical higher education institutions, how to implement the content of the health system of the educational educational environment A.V. Kabatskaya, L.V. Shuba, V.V. Shuba. URL: https://spppc.com.ua/index.php/journal/article/view/130. 


\section{Sadova M.A. EMPIRICAL RESULTS OF RESEARCH OF SIGNIFICANT DIFFERENCES IN VALUE ORIENTATIONS REGARDING PROFESSIONAL SELF-DETERMINATION OF GIFTED YOUTH}

The article analyzes the empirical results of research on significant differences in value orientations regarding the professional self-determination of gifted youth. The author describes the influence of value orientations on the professional self-determination of young people by such foreign authors: N. Eliot, S. Church, T. Friedel, O. Leggett, R. Mokhnyuk, P. Kirpichnyk, V. Kimmelblat, K. Kessel, J. Hochheimer, S. Almachi, Z. Okhrimenko, S. Ryan, I. Dessie, K. Little, M. Kabatska, O. Gitman, D. Horst. Differences in value orientations regarding the professional self-determination of gifted youth were studied by the following authors: G. Moberg, V. Garn, J. Veselom, K. Maurice, K. Campbell, S. Vernom, L. Assor, K. Nemiek, R. Makos, M. Sadova, V. Kapol, R. Svinarenko, K. Kosel.

It should be noted that on most scales of value orientations by gender, girls performed better in choosing a profession ("Self-direction", "Stimulation", "Reputation", "Conformity", "Humility", "Friendliness", "Universalism") than boys ("Power").

According to age differences, most scales of value orientations for the choice of profession were better performed by young children than adolescents. These are such scales as "Self-direction-thoughts", "Self-direction - actions", "Reputation", "Traditions", "Conformity - interpersonal", "Benevolence - care", "Universalism - nature".

On all scales that have passed the levels of significance in the value orientations for choosing a profession according to the level of academic giftedness, academically gifted children performed better, in contrast to untalented youth ("Self-direction - action", "Stimulation", "Power-domination", "Conformity - interpersonal").

Thus, it should be said that according to the relevant scales of values for choosing a profession in educational institutions where gifted youth study, university students performed better than high school students ("Conformity - rules", "Obedience").

Key words: value orientations, professional self-determination, levels of significance, differentiation, giftedness. 